\title{
Orthios as a Rhythmical Term
}

\author{
Nina Almazova
}

St. Petersburg State University, 7-9, Universitetskaya nab., St. Petersburg, 199034, Russian Federation; n.almazova@spbu.ru

For citation: Nina Almazova. Orthios as a Rhythmical Term. Philologia Classica 2019, 14 (2), 164-176. https://doi.org/10.21638/11701/spbu20.2019.201

Some ancient sources claim that the orthian nome was named so due to its rhythm. In order to estimate the probability of this assertion the author first examines known cases of op $\rho$ to c as a metrical or rhythmical term. After dismissing evidence which seems either mistaken or using o $\rho \theta เ o c$ in a non-technical sense, the author believes that the following meanings are reliably attested: (1.1) an iambic trimeter with only pure iambic feet (possibly the term could be applied to other uniform verses as well); (1.2) a cretic with a resolution of both longs; (1.4) a sequence $-\cup \cup--$; (1.6) an elongated iambic foot, which consists of a tetraseme and an octaseme syllable. Next, the author analyzes what is reported concerning the rhythm of the orthian nome. As authors of the classical period, who were still able to hear the piece performed, attribute

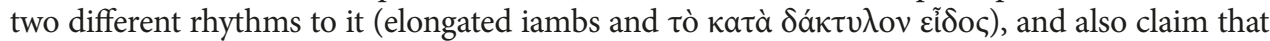
Terpander used orthian rhythm to create a particular version of the orthian melody, it follows

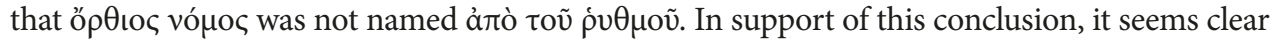
that the orthian nome was very well known to common people in the fifth century BC, so that its name must have been understood even by those who were no experts in rhythmical theory.

Keywords: Ancient Greek music, nomes, orthios, rhytmical terms.

My interest in the term ö $\rho \theta \iota \varsigma$ stems from an attempt to interpret the so-called

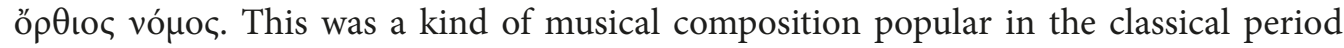
(Aristophanes, Eq. 1278-1279, identifies it as something that anyone with even a modicum of musical appreciation would certainly know). Evidence at our disposal shows that there were two types of orthian nome, ${ }^{1}$ the citharodic (sung to the cithara) ${ }^{2}$ and the auletic

${ }^{1}$ I do not think it plausible that aulodic orthian nomes were composed by Polymnestus (a supposition based on Ps.-Plut. De mus. 1134 C and D): see my article "Artistic Heritage of Polymnestus of Colophon", forthcoming in Mnemosyne.

${ }^{2}$ Hdt. 1. 24; Aristoph. Eq. 1278; Sch. Aristoph. Ach. 1042, Eq. 1278a, 1279a, Ran. 1282; Poll. 4. 65; Suid. a 1701, eı 146, $\lambda$ 753, v 478, o 574, 575, 585; Phot. Lex. a 1303, 1304, v 302 Theodoridis; cf. Aristoph. Eccl. 741 with Sch.

(C) St. Petersburg State University, 2019 
(played on the aulos). ${ }^{3}$ Following conflicting ancient sources, some scholars argue that the orthian nome was named for its rhythm, ${ }^{4}$ others for its pitch. ${ }^{5}$ In this paper I shall examine the probability of the former.

All testimonies that argue the case that the orthian nome was named according to its rhythm are late and belong to the same tradition, most fully represented in the Onomasticon by Pollux (4.65): ${ }^{6}$

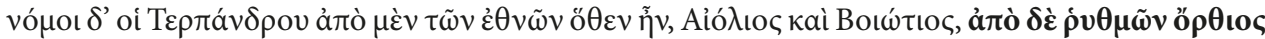

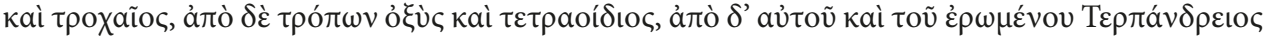
кaì Karíwv.

"The nomes of Terpander < got the following names $>$ : from the races to which $<$ Terpander $>$ belonged, Aeolian and Boeotian; from the rhythms, orthios and trochaios; from the melodic structure, oxys and tetraoidios; after himself and his beloved, Terpandreios and Kapion."

In order to estimate the probability of this claim, we must first consider the meaning of o $\rho \theta$ toc in metrical or rhythmical contexts.

1.1. Atilius Fortunatianus (Keil GL vol. VI p. 286. 16-18) likely names so an iambic trimeter with only pure iambic feet $(\cup-\cup-\cup-\cup-\cup-\cup-)$ :

nam versus qui ex hoc uno (sc. $\cup-$ ) est legitimus iambicus erit, quem Graeci ö $\rho \theta$ เov (Putschen :

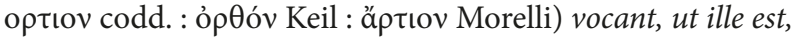

beatus ille qui procul negotiis.

"A verse which consists only of this kind <of foot>, will be legitimate iambic, the one which the Greeks call orthion, such as: (quot.)."

Cf. p. 287, 10-14:

iambicum hoc metrum, etiam si defuerit versui iambus vel rarus in eo fuerit, appellabimus. ille est

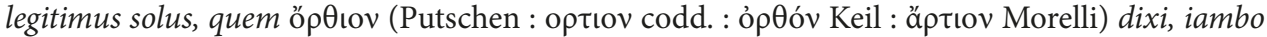
solo constat. sed ut diximus iam dactylicum hexametrum etiam eum dici, qui omnes spondeos habeat, ita et hic iambicus dicetur, quamvis unum iambum habeat,

pavidumque leporem et advenam laqueo gruem.

"We call this metre iambic, even if iambs are absent or rare in it. Legitimate is only the <iambic verse > which I called orthion, that is, which consists only of iambs. However, as I said above, a hexameter is called dactylic, even if it consists of all spondees; likewise, this verse will be called iambic, although it includes only one iambic foot: (quot.).”

3 Aristoph. Ach. 16 with Sch.; Dio 1. 1; Poll. 4. 73; Suid. o 573, х 171.

4 Müller 1882, 278-279; Sittl 1884, 288; Croiset 1914, 77; Abert 1899, 138; Bergk 1914, 9, ad Terp. fr. 2; Gentili 1988, 26 (with n. on p. 242); considered also by Barker 1984, 251 ("possible").

${ }^{5}$ Graf 1888, 512-523; Smyth 1904, 167; Salazar 1954, 278; 302; Del Grande 1960, 424; Pintacuda 1978, 43; id. 1982, 17 n. 1; Barker 1984, 252.

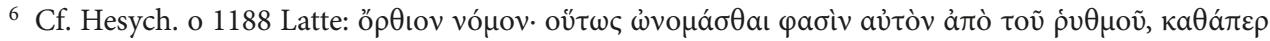

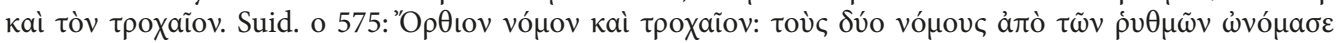

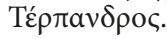


The reading of the Greek word used in both passages is not secure. As for the emendation ö $\rho$ Өıv, cf. ThLL IX. 2, p. 1057 s.v. orthius: writing ortius (as well as hortius and orcius) instead of orthius occurs regularly in Latin, and it seems likely that ö $\rho \tau \imath o v$ is nothing more than a peculiarity of orthography.

However, G. Morelli argues that the Greek term should be emended to áptıov, which corresponds to the Latin legitimus in several contexts. ${ }^{7}$ It should be noted that both terms mean 'acatalectic' in all the cases he adduces, a meaning which would be out of place here, since Atilius is comparing 'correct' iambic verse with those using resolutions or realizing ancipitia as longs, and not with catalectic ones. ${ }^{8}$ Yet it may be supposed that ä $\rho \tau \iota \varsigma$, , just like legitimus in Atilius' passages cited here, had a broader meaning 'correct, unchanged, taken in its integrity, free of licenses'.

It is not clear from Attilius whether "the Greeks" used the word to describe only iamb or other metres as well. To my mind, it looks more like a generic term than a designation of a particular sequence.

1.2. The term ö $\rho \theta$ เo is applied to a cretic with a resolution of both longs $(\cup \cup \cup \cup \cup)$. Diomedes, Ars gramm. 3, Keil GL vol. I p. 481. 13-14:

orthius ex brevibus quinque temporum totidem.

"Orthius of five shorts, of the same number of morae."

Anon. Ambr. p. 232. 10-11 Studemund:

ö $\rho$ เ

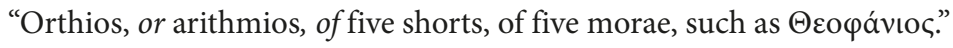

O. Crisius ${ }^{9}$ suggested that a common trait of the cases 1.1 and 1.2 is of $\rho \theta$ to

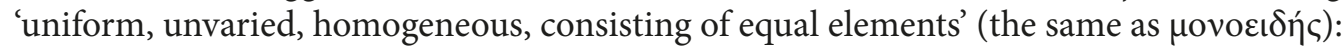

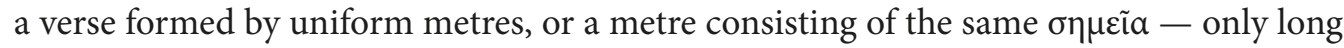
or only short syllables. Judging by 1.2, this figurative meaning might be derived from 'straightforward' rather than 'true, correct' (cf. legitimus in 1.1). However, Atilius' explanations seem to imply that a hexameter formed of all spondees was not called ö $\rho \theta \iota$ เ .

1.3. In Alcidamas Od. 25 (p. 33 Avezzù = Mus. fr. 103 Bernabé) a verse attributed to

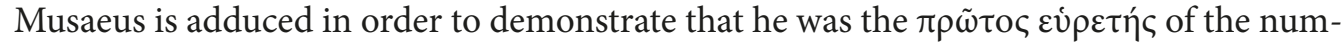
bers. Later Cassius Longinus (Proleg. in Hephaest. 5, p. 85.5 Consbruch), Georgius Choeroboscus (Sch. in Hephaest. p. 180. 3 Consbruch) and Anonymus Ambrosianus (p. 231. 7 Studemund), all derived from the same source, quote this verse as proof that the polyse-

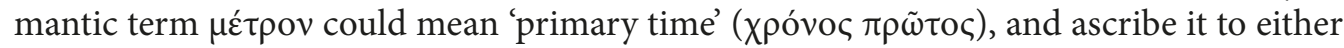
Orpheus or the Pythia:

7 Morelli 1998, 273-274.

8 Addressing this problem above, Attilius uses the terms catalecticum, acatalectum, hypercatalecton and brachycatalecton (p. 286, 26-287, 9).

9 Crusius 1887, 1392-1393. 


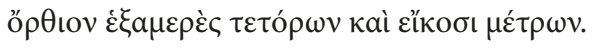

"orthion of six parts (= feet), of twenty-four metres (= primary times)"

The reference must be to the hexameter. ${ }^{10}$ In the lack of context it is not evident whether ö $\rho$ เov was used as a technical term, which would then signify this kind of verse - or merely as an epithet (possibly meaning 'sonorous' ${ }^{11}$ ). The latter seems more plausible, given that references to the Homeric metre are in excess supply beginning from the classical period; ${ }^{12}$ however, calling it ob $\rho$ to s is otherwise unattested not only by $\mathrm{Al}$ cidamas' time, but even later. Crusius ${ }^{13}$ took it for granted that ö $\rho \theta$ เo term in this case and argued that it meant a lyrical hexameter consisting of non-contracted dactyls in every foot except the last one (as in Alcman fr. 26 Page). Thereby he sought

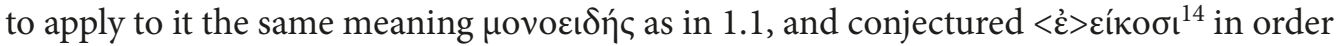
to use this line as an example for his hypothesis. Yet the verse itself seems to give no sufficient reason for such a conclusion (not to mention the final spondee that would anyway destroy the alleged uniformity).

1.4. Diomedes (Ars gramm. 3, Keil GL vol. I, p.481. 24-25) applies the name orthius not only to 1.2 , but also to a sequence $-\cup \cup--:^{15}$

orthius ex longa et duabus brevibus et longis duabus temporum octo.

"orthius of a long, two shorts and two longs, of eight morae."

At the same time Anonymus Ambrosianus, whose excurse on pentasyllabic feet is apparently cognate with that of Diomedes, provides another name for this sequence, namely

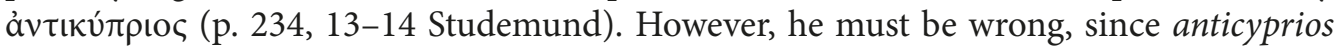
is the opposite of cyprios ( $\cup-\cup \cup-$ : Anon. Ambr. 233. 25-26 Studemund conforms to Diomed. p. 482, 4-5 Keil on this point), so its scheme is $-\cup--\cup$, as in Diomedes (p. 482. 5-6 Keil).

1.5. Anonymus Ambrosianus (p. 234. 5-6 Studemund) also uses the term ö $\rho \theta$ เо twice and records its even more exotic meaning: $-\cup-\cup \cup$.

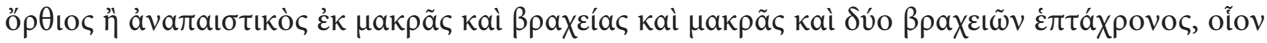

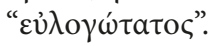

"Orthios or anapaistikos, of a long, a short, a long and two short syllables, of seven morae, such

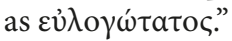

Once again, there is a divergence: Diomedes (p. 481. 28-29 Keil) calls this sequence

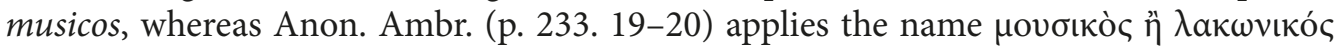

10 The invention of hexameter was ascribed to Orpheus: Kern 1922, test. 106.

11 See Almazova 2020, forthcoming.

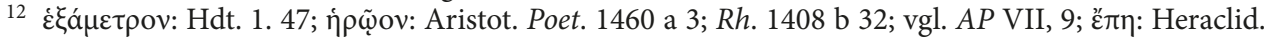
ap. Ps.-Plut. De mus. 1132 C.

13 Crusius 1887, 1393.

14 The conjecture is in itself implausible, since it is hardly possible that both the mss. of Alcidamas and of the grammarian tradition would have gone astray by copying the verse.

15 Nowadays this colon is generally known as adonius: cf. Sacerd. Keil GL vol. VI, p. 516, 22-517, 3. 


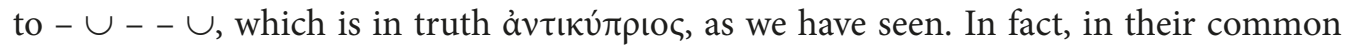

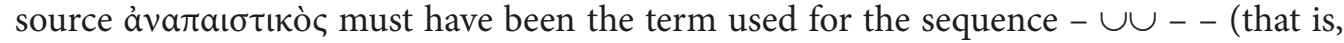
orthius in Diomedes, see 1.4 above), since its opposite $\cup--\cup \cup$ is called antanapaestus

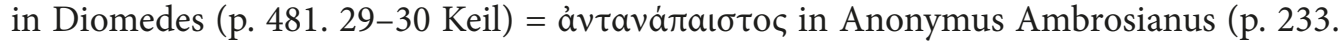
13-14 Studemund).

Apparently ö $\rho \theta ı \varsigma$ is misplaced in the account of Anonymus. W. Studemund ${ }^{16}$ suggested a very plausible explanation of the divergences in order and subject matter. PseudoDraco, a Byzantine scholar who reproduces the same tradition $\pi \varepsilon \rho i$ excurse on feet was once exposed as a diagram or a table. ${ }^{17}$ Later grammarians must have copied it as a text, thereby displaying various kinds of imprecision, such as misaligning explanations and examples of certain terms. Therefore, we have good reason not to believe that ô $\rho$ เo s ever acquired the meaning $-\cup-\cup \cup$.

Double names, ô $\rho$ to duced by Anonymus Ambrosianus, but neglected by Diomedes, perhaps helped to reduce the consequences of using the term ö $\rho \theta$ เo in two different meanings in the same treatise. I cannot imagine in what way the direct meaning of the adjective ob $\rho$ toc could be extended to suit the case $-\cup \cup--$.

1.6. Still another meaning is most clearly explained in Aristides Quintilianus: ó $\rho$ to

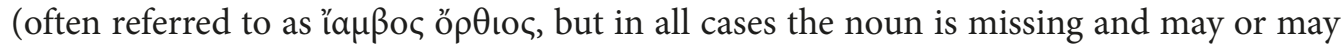
not be understood from the context) is an elongated iambic foot with the first syllable of

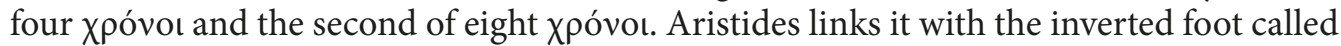

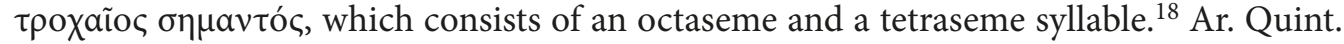
1. 16, p. 36, 1-6 W.-I.:

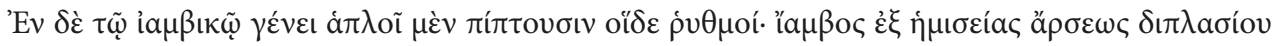

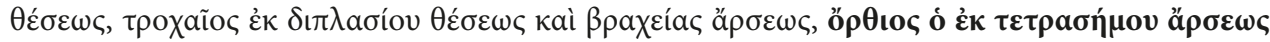

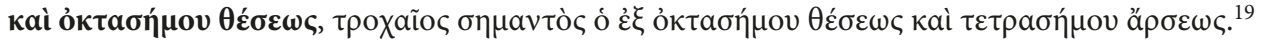

"In the iambic genus, the following rhythms fall within the simple class: iamb of a half arsis and a double thesis; trochee of a double thesis and a short arsis; orthios of a tetraseme arsis and octaseme thesis; and marked trochee of octaseme thesis and tetraseme arsis." ${ }^{20}$

This extremely slow rhythm is described as noble and dignified: ó $\delta \dot{\varepsilon}$ ö $\rho \theta ı$ ı (sc.

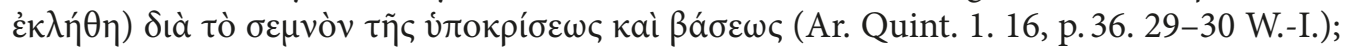

16 Studemund 1886, 232.

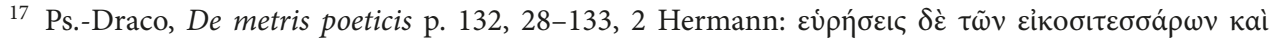

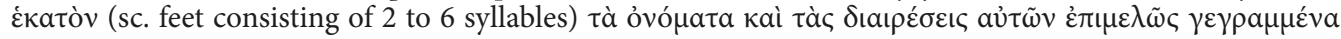

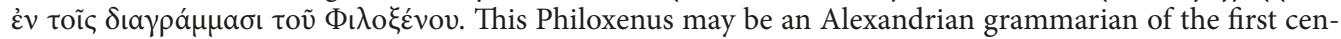
tury BC, cf. Suid. $\varphi$ 394; Westphal 1867, 226-229; Wendel 1941, 199. Anonymus Ambrosianus indicates

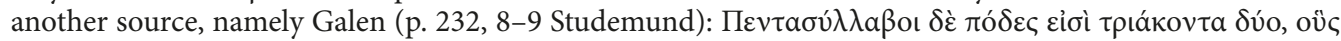

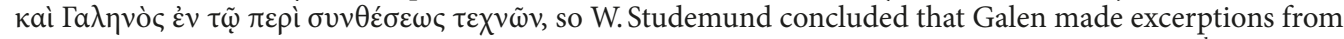
Philoxenus. Westphal denies that this could have been the person meant by Ps.-Draco in the $14^{\text {th }}$ cent.

18 For the history of interpreting these terms, see Marchetti 2009, 172-173.

19 Aristides is the source (see Stahl 1971, 53) of Martianus Capella (9. 985, p. 526, 10 sqq. Dick), who offers a rather close translation of this passage with a supplement: orthius vero, qui ex tetrasemi elatione et octasemi positione constabit, ita ut duodecim tempora hic pes recepisse videtur, atque habet propinquitatem aliquam cum iambico pede.

20 Translation: Mathiesen 1983, 98. 


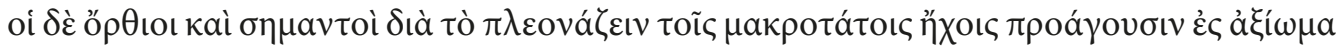
(2. 15, p. 83. 4-6 W.-I.).

The same two sequences are mentioned in a fragment of a rhythmical treatise preserved in POxy $9+2687$, col. III 30-IV 1:

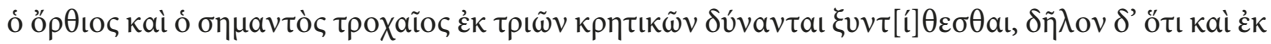

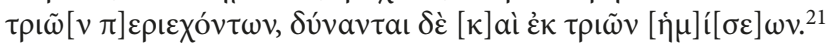

"The orthios and the marked trochee could be constructed from three cretics; it could evidently be made out of three "encompassers", and it could also be made of three halves." 22

The author is concerned with the license of lengthening long syllables to the value of three or more time units, and then makes a digression (III. 23-35, IV.1-20) dedicated to the limits of this license in poetical practice. He arrives at a conclusion that not everything that is theoretically possible proves to be practically suitable. Rhythmical units changed to such an extent that they can hardly be recognized must be used sparsely and alternated with unaffected ones, and on the whole the appropriateness of any such experiment must be judged by aî $\theta \varepsilon \sigma ı \varsigma^{23}$

For the reference to the same pair of rhythms, the orthios and the marked trochee, in Pseudo-Plutarch De mus. 28, 1140 F see below 2.2.

Concerning each of these three sources scholars have supposed, with various degrees of probability, that they derived from some work of Aristoxenus. I think this next to certain as regards chapter 28 of Pseudo-Plutarch. The inventions of Terpander are enumerated in this passage in order to demonstrate that he, like other old-time musicians, did not avoid innovations, yet still managed to keep to noble and solemn music - unlike the decadent composers of the classical period. This 'leitmotiv' in De musica may be convincingly attributed to Aristoxenus: he is mentioned by name in $1134 \mathrm{~F}$ and $1136 \mathrm{D}$ on similar occasions, while a number of other passages contrasting old and new music (including ch. 12 closely connected with ch. 28-30) reveal similarities to Aristoxenus both in subject and vocabulary (cf. in particular Aristox. fr. 70 Wehrli = Themist. Or. 33. 1, 364 B-C). ${ }^{24}$

The attribution of the rhythmical papyrus is debated. Whereas its earlier editors ${ }^{25}$ used to ascribe the treatise to Aristoxenus himself or at least to someone of his school, this attribution was refuted by Ch. Marchetti and L. Calvié on the basis of non-Aristoxenic

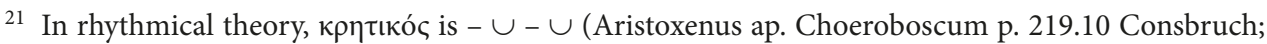
Ar. Quint. 1. 17, p. 38. 3-5 W.-I.). Thus, the named substitution requires using a combination of six timeunits as equivalent to four. The meaning of $\pi \varepsilon p \iota \varepsilon ́ \chi \chi v \tau \varepsilon \varsigma$ ("encompassers") is debated. Perhaps these are syllables elongated to the value of three (or four) time units and thus embracing an entire rhythmic marker - arsis or thesis (Rossi 1988: 24; Calvié 2014, 13; Marchetti 2009, 261); or a combination of the outside syllables of the sequence (cf. Ar. Quint. 1. 22, p. 44.28 W.-I.) - in the case of a cretic this will be $-\cup$ (Pearson 1990, 83); or else a group of syllables which comprises an internal ratio (Marchetti 2009, 261). 'H have been interpreted as shorts (halves of longs: Grenfell, Hunt 1898, 18; Rossi 1988: 27; Calvié 2014, 13; cf. Ar. Quint. 1. 16, p. 36. 2 W.-I.), as longs (halves of elongated syllables: Marchetti 2009, 261), and as - $\cup$ (halves of cretics, Pearson 1990, 83).

22 Translation: Marchetti 2009, 244 with minor changes.

23 See Calvié 2014, 13-14.

24 Weil, Reinach 1900, 53; Visconti 1999, 135-137; Meriani 2003, 75-79.

25 From Grenfell, Hunt 1898 up to Pearson 1990. Cf. Rossi 1988, 9: "in fatto di armonica e di ritmica la teoria, nel mondo antico, è quella di Aristosseno, che non ha rivali. La vera alternativa è, piuttosto, tra ipsissima verba del maestro e adattamento scolastico della materia". See Calvié 2014, 24-26 on the status quaestionis. 
terminology and concepts. Calvié ascribes the fragment to a representative of a different school, probably active in the $5^{\text {th }}$ century BC. ${ }^{26}$

As regards Aristides Quintilianus' treatment of rhythmical matters (1. 13-20 and 2. 15), some parts are acknowledged to reflect Aristoxenus' theory, but 1. 16, which contains the description of o $\rho \theta ı$, , as well as the entire section 15-17, must come from another source. ${ }^{27}$

Anyway, even if only the passage of Pseudo-Plutarch proves to arise from Aristoxenus, this is enough to conclude that already by the Classical period the elongated iamb was known and described as ó $\rho \theta ı \iota_{\text {ç. }}{ }^{28}$

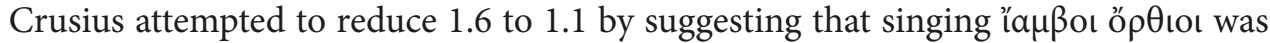
accompanied by uniform beats of the cithara, ${ }^{29}$ yet analyzing the accompaniment rather than the song itself seems unparalleled. Th. Bergk, referring to 1.1, supposed that ob $\beta$ เo was the original name of the iambic foot $\cup$ - inherited by its quadrupled version, ${ }^{30}$ but this is at variance with 1.2-1.5. Aristides Quintilianus ascribes the meaning 'noble, elevated' ( $\sigma \varepsilon \mu \nu$ ó $)$ to it, but, so far as I know, this sense of the adjective ó $\rho \theta ı$ เo is not otherwise attested.

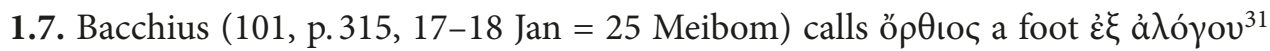

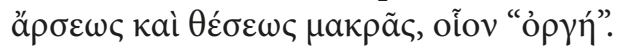

The subject matter (but not the order and not always the terminology) of Bacchius' $\$ 101$ corresponds rather closely to the treatise of Aristides Quintilianus 1. 15-17: both passages apparently reflect the same tradition (that of the so-called $\sigma v \mu \pi \lambda \varepsilon \dot{\varepsilon} \kappa \nu \tau \varepsilon \varsigma$, Ar. Quint. 1. 18, p.38. 15-17 W.-I.). ${ }^{32}$ This makes the unparalleled explanation of of $\rho \theta$ เoc in Bacchius suspect. According to the hypothesis of R. Westphal elaborated by C. von Jan, Bacchius (or whoever composed $\$ 101$ ) had at his disposal a more detailed account than his own (we can judge on its contents by Aristides), yet he confined himself to describing each time only one species of ten main rhythms. As he made such an excerption, his eye slipped from the term ö $\rho \theta ı$ ı (probably used in the same meaning as 1.6) to the description of an 'irrational' iamb. ${ }^{33}$ If so, his evidence has no value, and a lacuna must be postulated after ö $\rho \theta$ เoc. ${ }^{34}$

${ }^{26}$ Marchetti 2009, 237; Calvié 2014, 30-54.

27 Westphal 1867, 85-104.

28 A further reason makes this still more probable. It has been argued while interpreting El. Rhythm. 2 p. 21. 26-22.18 Pighi that in this passage Aristoxenus is thinking specifically of the same elongated feet as described by Aristides: the orthian, the marked trochee and the paean epibatos (Weil 1855, 400-401; Marchetti 2009, 171; 175).

${ }^{29}$ Crusius 1887 p. 1393: “Jene gedehnten, aus langen Silben bestehenden ö $\rho \theta$ เo trugen diesen Namen

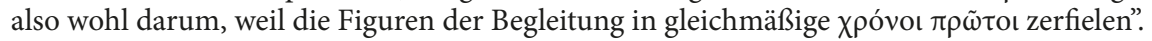

30 Bergk 1914, 9: "iambus autem a principio videtur ő $\rho$ เo vocatus esse, unde etiam postea versus, qui ex puris iambis fuit compositus, hic nomen sibi vindicabit” (with a reference to Atilius).

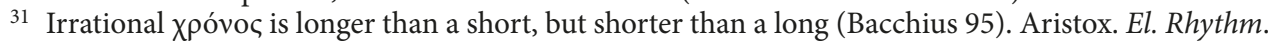
2. p. 22. 19-29 Pighi and Dion. Hal. De comp. 20 speak of an irrational foot whose time-relations cannot

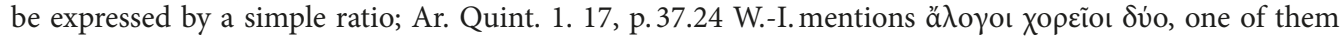

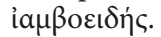

32 Westphal 1867, 94-96; Jan 1891, 558, 567.

33 Westphal 1867, 96; Jan 1891, 567.

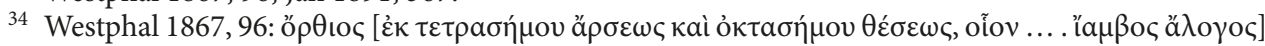

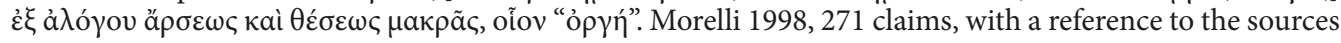


1.8. Outside rhythmical treatises it is not quite clear if o $\rho \theta เ \circ$ applied to a rhythm is a technical term, and what it means. In Athenaeus $(14.29,631 \mathrm{~B})$ we find a recom-

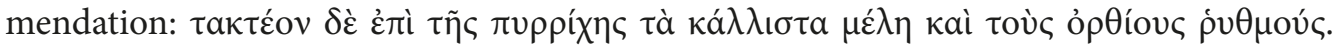
Elongated iambs (1.6), it appears, were hardly appropriate for an active military dance. ${ }^{35}$ E. Graf supposed that ö $\rho \theta$ เo $\rho$ p $\theta \mu$ oí were resolved cretics of five shorts (1.2). ${ }^{36}$ However, after "the most beautiful melodies" (and considering the plural number tov̀ ò $\rho \theta$ íous $\dot{\rho} v \theta \mu o v ́()$ a more general attribute suggests itself. N. Golinkevich understood it as 'excited' ('возбужденные'), ${ }^{37}$ thus applying a characteristic of the orthian nome most often referred to in late antiquity ${ }^{38}$ to the rhythm of the pyrrhic dance.

The probability of this meaning is confirmed by a passage in Posidonius (fr. 417, p. 338 Theiler [p. 452. 15-453. 2 Müller] = Galen. De placitis Hippocratis et Platonis 5. 6. 20). Following Plato, the philosopher advises the use of different $\dot{\rho} \theta \mu \mu_{\text {oi }}$ and $\dot{\alpha} \rho \mu o v i ́ a$ in order to bring up different kinds of people:

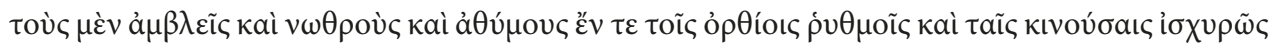

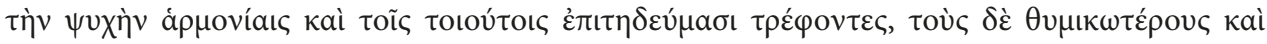

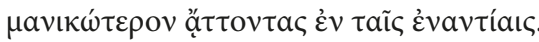

"...bringing up dull, sluggish and spiritless people with the help of orthioi rhythms, and melodic structures that move the soul intensely, and suchlike practices, and hot-spirited and people given to madness with the help of the opposite ones."

Here again ö $\rho \theta ı$ เo $\rho \cup \theta \mu o$ are 'energetic', 'vigorous', 'calling for activity', ${ }^{39}$ a meaning probably arising from the generally known definition of the orthian nome.

On the whole, considering sparse and contradictory evidence one can conclude that o $\rho \theta t o \varsigma$ as a rhythmical term was scarcely used, and its meaning was not widely established. Only in 1.6 is there a possibility that it dates back to the classical period. As for applying it to pentasyllabic 'feet', it was surely a late, unhappy and unpopular invention.

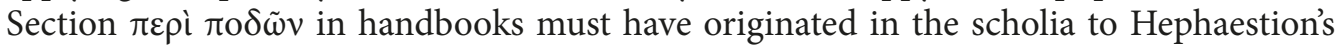
Enchiridion; ${ }^{40}$ for the most part grammarians conclude it with lists of four-syllabic feet, and some of them either note that there is no point in reviewing five-syllabic sequences, ${ }^{41}$ or else affirm that they have no particular names. ${ }^{42}$

1.3 above, that ö $\rho \theta เ$ s in Bacchius should be identified with the dactyl (which is notoriously absent from his list).

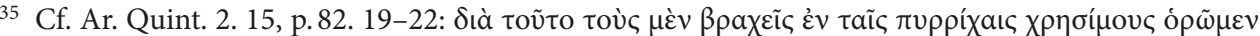

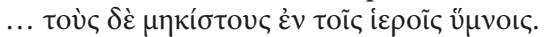

36 Graf 1888, 512 n. 1.

37 Golinkevich 2010, 342.

38 Dio 1.1 etc.; see Almazova 2020 forthcoming, esp. n. 6 and 12.

39 The translation of De Lacy 1978, 331 is meaningless: "high-pitched rhythms".

40 Westphal 1867, 196-197; 203; 206-207; 227-229.

${ }^{41}$ E. g. Mallius Theodorus (Keil GL VI, p. 588, 1-5): Pentasyllabos etiam quidam et hexasyllabos pedes, quos Graeci syzygias vocant, faciendos crediderunt, quorum nobis superflua et inanis opera repudianda est, cum eorum etiam pedes, quos supra enumeravimus, complures ab omni metrica disciplina alieni sunt.

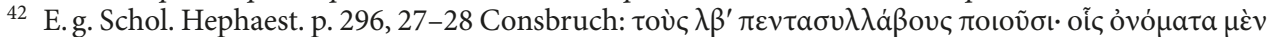

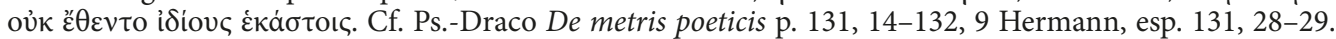
Marius Victorinus (Keil GL VI, p. 48, 28): Hac inspectione conicere poteris, quem ad modum ex disyllabis et trisyllabis pentasyllabi, sed et geminatis trisyllabis hexasyllabi pedes formari videantur, quorum syllabatim per tempora species comprehendi poterunt. Nam etiamsi propriis nominibus, ut alii pedes, minime exprimuntur, tamen situ syllabarum et substantia temporum manifesti sunt. 
Having established the attested meanings of o $\rho \theta$ to in the rhythmical sphere, we must analyze what is reported concerning the rhythm of the orthian nome.

2.1. According to Glaucus of Rhegium (Ps.-Plut. De mus. 1133 F), some people ar-

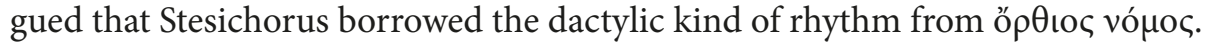

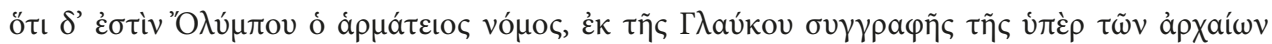

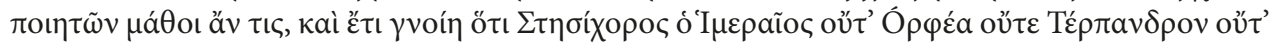

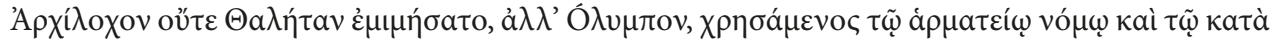

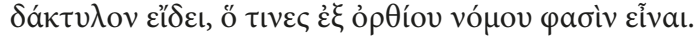

"The fact that the chariot nome was the invention of Olympus may be learned from Glaucus' book about the ancient poets, which also informs us that Stesichorus of Himera took as his model not Orpheus or Terpander or Archilochus or Thaletas, but Olympus, since Stesichorus used the chariot nome and the dactylic species of rhythm, which some people say is derived from the orthian nome."43

Both Glaucus and his opponents recognized the nomes by ear and could have no doubts as regards to their rhythms - only the source of Stesichorus' borrowing was subject to discussion. Hence this passage provides irrefutable evidence that the rhythm katò $\delta a ́ k \tau u \lambda o v$ was appropriate for the orthian nome - but not that it was the only one.

2.2. Another passage in Pseudo-Plutarch (De mus. 1140 F) has a different source, which is in all probability Aristoxenus, as argued above. It is claimed that olden-day musicians, including Terpander, admitted innovations, but never violated good taste. Unfortunately, the text is corrupt:

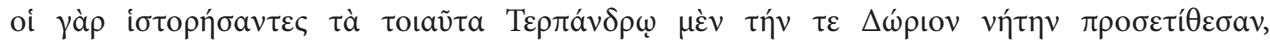

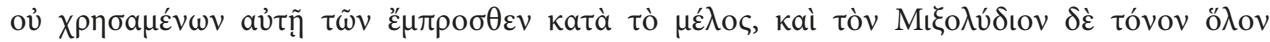

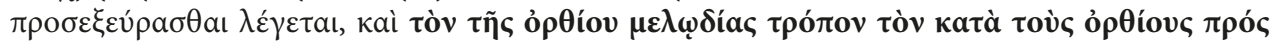

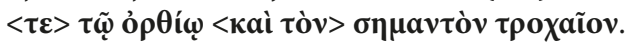

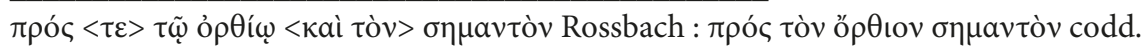

"Students of such matters have ascribed to Terpander the introduction of the Dorian nete, which has not been used in the melody by his predecessors. He is also said to have invented the entire Myxolydion tonos, and the variety of orthian melody that goes with the orthian foot, and in addition to the orthian foot the marked trochee as well." ${ }^{44}$

Accepting the emendation, one has to suggest that $\mu \varepsilon \lambda \omega \delta$ ía is a generic term, probably meaning the same as vó $\mu$ ov; трó

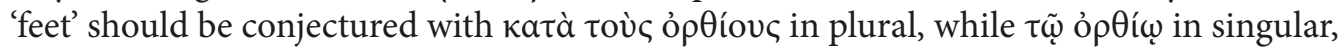

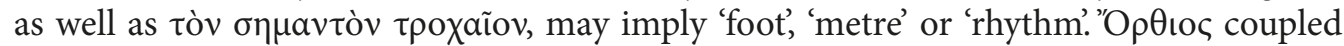

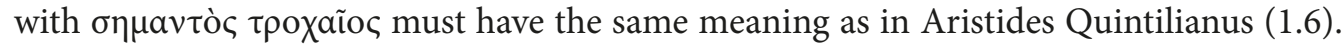
Thus, Terpander will have created a new kind of the orthian nome distinguished by the

43 Translation: Barker 1984, 213 with minor changes.

44 Translation: Barker 1984, 233 with minor changes. 
orthian rhythm, and also have invented the marked trochees after the same pattern as the orthian iambs, though it is not clear if he applied them to the orthian melody. Using o $\rho \theta$ toc in various meanings and numbers in the same phrase, with two nouns missing, renders the text still suspect despite the emendation, but, as far as I know, no alternative reading or understanding has been ventured. ${ }^{45}$ Interpreted in this way, the passage makes it clear that one, and only one, kind of orthian nome used orthian iambs as its rhythm.

2.3. In a comment on the passage from the Frogs by Aristophanes, where Euripides

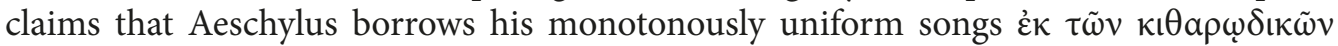
$v o ́ \mu \omega v$ (Ran. 1282), a certain Timachidas argued that it was specifically the orthian nome that was implied. ${ }^{46}$ If so, it follows that numerous examples adduced in lines 1264-1277 and 1284-1295 in order to mock Aeschylus' lack of inventiveness illustrate the rhythm of this nome, namely acatalectic, sometimes contracted dactylic sequences of different length

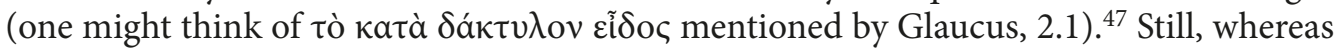
such a rhythm was indubitably typical of citharodic tradition in general, there are reasons to doubt whether Timachidas possessed reliable information concerning the orthian nome in particular, rather than invented these data himself. Aeschylus mentioned of $\rho \theta$ เo

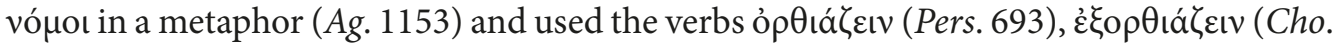

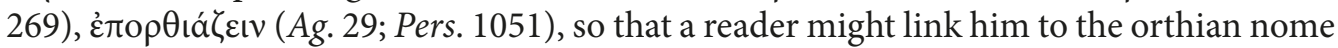
simply by studying his pieces.

2.4. Lastly, there is a fragment ascribed to Terpander (fr. 2 Gostoli $=P M G 697$ Page), which, as Didymus ${ }^{48}$ argued, comes from an orthian nome.

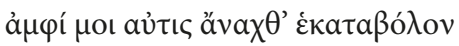

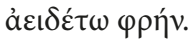

"Let my soul sing again of the far-shooting lord..."

As is usually the case with the scholiasts' assertions concerning nomes of the classical period, it may be put into question whether Didymus possessed real information, or just advanced his own conjecture. The fragment survived in lemmata dedicated to the

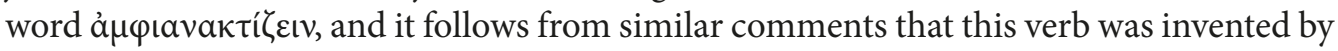
comic poets to mock the beginning ả $\mu \varphi \grave{i} a ̈ v \alpha \kappa \tau \alpha$ too often used by composers of various nomes (orthian, Boeotian, Aeolian: Phot. Lex. a 1304), proems and dithyrambs (Suid. a $1700)$.

45 Rossbach 1854, 100: “Terpander soll, so sagt Plutarch [28], die Weise der orthios melodia nach orthischen Rhythmen und nach Analogie des Orthius auch den Trochaeus semantus erfunden haben”. The same is the understanding of Volkmann 1856, 32; 116; Westphal 1865, 52; Weil, Reinach 1900, 104-107; Ballerio 2000, 85. In my turn I am not able to propose a more plausible hypothesis.

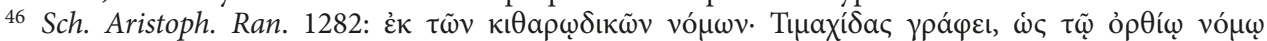

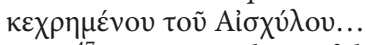

47 For my analysis of this passage see Almazova 2016, 109-113.

48 Didymus' name is mentioned in an interlineary scholium in P. Flor. 112, see Luppe 1978, 161: 1.

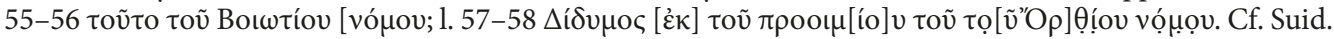

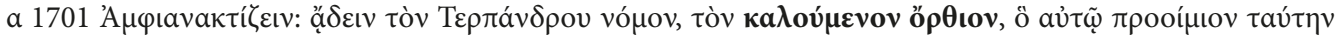

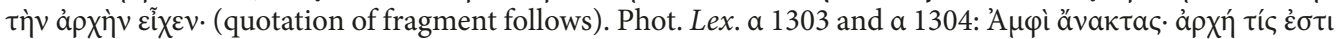

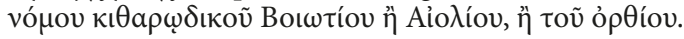


As edited by A. Gostoli, the fragment consists of an alcmanium (4 da) and a reizian $(\cup-\cup--)$. Previously, many scholars, motivated by indications in Pseudo-Plutarch that Terpander used epic metre (De mus. $1132 \mathrm{~B}$; D-E; $1133 \mathrm{~B}-\mathrm{C}$ ), proposed changing the text into a hexameter. ${ }^{49}$ Yet such a reason for emendation looks arbitrary: as proved by 1140 F, Terpander did not confine himself to a single metre. Moreover, B. Gentili plausibly suggested that $\ddot{\varepsilon} \pi \eta$ in Pseudo-Plutarch included not only hexameters, but also dactyloepitrites. ${ }^{50}$

Juxtaposing the first and the second group of testimonies we must admit that technical meanings of o $\rho \theta$ เo attested in rhythmical treatises suit the rhythms associated with the orthian nome in our sources. Orthian iambs (1.6) seem to be explicitly attributed

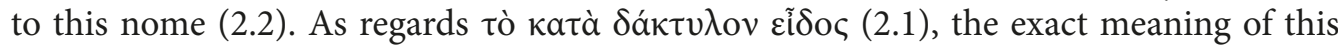
term is not known, ${ }^{51}$ but it looks likely that such a category could embrace the sequence $-\cup \cup--(1.4)$ as well as verse made up of pure dactyls $(1.1 ; 1.3$ ?) of the type beloved by Aeschylus (2.3), or even of all longs (1.2), such as ascribed to Terpander (fr. 3 Gostoli $=$ PMG 698 Page). Only the structure of Terpander's verse (2.4) seems at odds with what

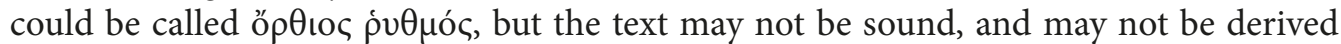
from an orthian nome.

Nevertheless, a theory of naming ö $\rho$ เо ऽ vó $\mu$ oৎ by rhythm must be refuted, since it

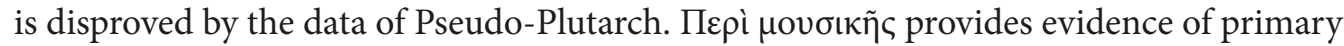
importance, i.e. by the authors who could still hear the orthian nomes with their own ears (2.1 and 2.2). Which is more, the rhythms of these nomes in both passages are not subject to discussion; they are mentioned as something established and form a point of departure for conclusions about their invention or transmission. Now, Glaucus of Rhe-

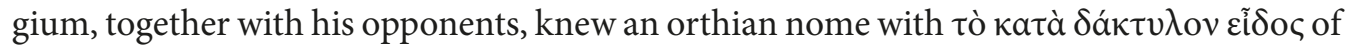
rhythm, and some people either contemporary or prior to Aristoxenus claimed that using orthian iambs in a particular version of this nome was an invention of Terpander. It seems evident that orthian iambs can by no means be referred to the dactylic kind, so two different rhythms are reliably attested for this piece. Moreover, it is obvious from the report about Terpander's innovations (if interpreted correctly) that the orthian melody already existed before orthian feet were applied to it, and this rhythm helped to create only one of

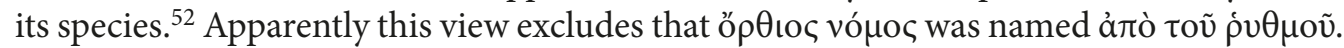

Later on, after the practice of writing rhythmical treatises developed, the very existence of o $\rho \theta t o \varsigma$ as a technical term could provoke some scholar to connect it with the orthian nome, well known to grammarians by references in classical literature, but hardly preserved as a musical piece by that time.

This conclusion may be supported by general observations. The name 'orthian nome' is known - indeed very well known, being the first thing that springs to mind when con-

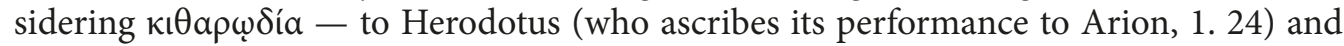

49 åd $\delta \varepsilon ́ \tau \omega<\dot{\alpha}>\varphi \rho \eta ́ v$ : Ernesti in Hermann 1799, 363; accepted by Schneidewin 1839, 237; Page 1962,

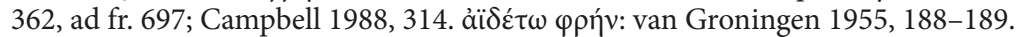

50 Gentili 1977, 34-36.

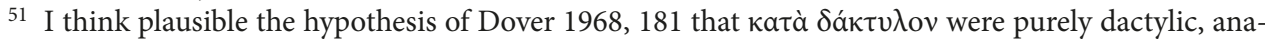
paestic, and spondaic sequences without a "remainder" at the beginning or the end. See Almazova 2016.

52 Some scholars even suggested that the rhythm was named by the nome and not vice versa: Volkmann 1856, 116; Weil, Reinach 1900, 105; Lasserre 1954, 24-25; Gamberini 1979, 243 n. 2; Cristante 1987, 370. 
Aristophanes (Eq. 1279; cf. Eccl. 741; Ach. 16). Therefore, it is not likely to be a scholarly invention based on analyzing the rhythm of existing pieces (in any case these pieces ought to have their own name even before such analysis). Commoners such as Dicaeopolis must have always had an understandable term for this nome, which would not require such complicated technical matters as counting syllables and xpóvor $\pi \rho \tilde{\omega} \tau o$. I hope to demonstrate in a forthcoming article that evidence dating to the classical period does indeed confirm the existence of such an accepted alternative explanation.

\section{References}

Abert H. Die Lehre von Ethos in der griechischen Musik. Ein Beitrag zur Musikästhetik des klassischen Altertums, Sammlung musikwissenschaftlicher Arbeiten von deutschen Hochschulen 2. Leipzig, Breitkopf \& Härtel, 1899.

Almazova N. Daktylus und Enhoplios in Damons Rhythmuslehre. Hyperboreus 2016, 22 (1), 94-126.

Almazova N. Orthios as a Quality of Sound, Philologia Classica 2020, 15 (1), forthcoming.

Ballerio R. (transl., comm.) Plutarco. La musica. Milan, Biblioteca Universale Rizzoli, 2000.

Barker A. Greek Musical Writings. I. The Musician and his Art. Cambridge, Cambridge University Press, 1984.

Bergk Th. Poetae lyrici Graeci. III. Lipsiae, Teubner, 1914.

Calvié L. Le fragment rythmique du P. Oxy. $9+2687$ attribué à Aristoxène de Tarente. $R P h$ 2014, 88 (1), 7-54.

Campbell D. A. (ed.) Greek Lyric II, Loeb. Cambridge, Mass., Harvard University Press, 1988.

Cristante L. (intr., transl., comm.) Martiani Capellae de nuptiis Philologiae et Mercurii liber IX. Padova, Antenore, 1987.

Croiset A. Histoire de la Littérature grecque. Tome second. Lyrisme - Premiers prosateurs. Hérodote. Paris, Fontemoing et $\mathrm{C}^{\mathrm{ie}},{ }^{3} 1914$.

Crusius O. Zur Nomosfrage. Wochenschr. f. kl. Philol. 1887, 45, 1380-1395.

De Lacy P. H. (ed.) Galenus. On the Doctrines of Hippocrates and Plato. I. Corpus medicorum Graecorum 5. 4. 1. 2. Berlin, Akademie-Verlag, 1978.

Del Grande C. La metrica greca: Estratto da: Enciclopedia Classica. Sezione II: Lingua e letteratura. Volume V: La lingua greca nei mezzi della sua espressione, a cura di Carlo Del Grande. Tomo II. Torino, Società editrice nazionale, 1960.

Dover K. J. (ed.) Aristophanes. Clouds. Oxford, Clarendon Press, 1968.

Gamberini L. (ed., comm.) Plutarco Della musica. Florence, Olschki, 1979.

Gentili B. Preistoria e formazione dellesametro. QUCC 1977, 26, 7-37.

Gentili B. Poetry and its Public in Ancient Greece: from Homer to the Fifth Century. Transl., with an introd., by A. Th. Cole. Baltimore - London, Johns Hopkins Univ. Press, 1988.

Grenfell B., Hunt A. The Oxyrhynchus Papyri I. London, Egypt Exploration Society, 1898.

Golinkevich N. (tr.), Athenaeus. The banquet of the wise, IX-XV. Moscow, Nauka Publ., 2010. (In Russian)

Gostoli A. Terpander. Roma, ed. dell'Ateneo, 1990.

Graf E. Nomos orthios. RhM 1888, 43, 512-523.

Hermann G. Aristophanis Nubes cum scholiis recensuit et adnotationes Io. Aug. Ernestii suasque addidit G. H. Lipsiae, Fritsch, 1799.

Jan C.von. Die Metrik des Bacchius, RhM 1891, 46, 557-576.

Kern O. (ed.) Orphicorum fragmenta. Berolini, Weidmann, 1922.

Lasserre F. (ed.) Plutarque. De la musique. Texte traduction commentaire précécés d'uneétude sur léducation musicale dans la Grèce antique. Olten — Lausanne, Urs Graf, 1954.

Luppe W. Zum Aristophanes-Kommentar P. Flor.112/ Nr. 63 Austin. ZPE 1978, 28, 161-164.

Marchetti C. C. Aristoxenus' Elements of Rhythm: Text, Translation, and Commentary with a Translation and Commentary on POXY 2687. New Jersey, Diss. Rutgers. 2009.

Mathiesen Th. J. (transl., intr., comm., notes). Aristides Quintilianus On Music in Three Books. New Haven London, Yale University Press, 1983.

Meriani A. Tracce Aristosseniche nel De musica pseudoplutarcheo, in: id. Sulla musica greca antica. Studi e ricerche (Università degli Studi di Salerno. Quaderni del Dipartimento di Scienze dell'Antichità 28), Salerno, Guida Editore, 2003, 49-81. 
Morelli G. Trimetri ỏ $\rho$ oó e trimetri äptıo nel capitolo De iambico di Attilio Fortunaziano. Eikasmos 1998, 9, 267-278.

Müller K. O. Geschichte der griechischen Litteratur bis auf das Zeit Alexanders. Erstes Band. Nach der Handschrift des Verfassers herausgegeben von Dr. Eduard Müller. Vierte Auflage, mit Anmerkungen und Zusätzen bearbeitet von Emil Heitz. Stuttgart, A. Heitz, 1882.

Page D. L. Poetae melici Graeci. Oxford, Clarendon Press, 1962.

Pearson L. Aristoxenus Elementa Rhythmica: The Fragments of Book II and the Additional Evidence for Aristoxenean Rhythmic Theory. Oxford, Clarendon Press, 1990.

Pintacuda M. La musica nella tragedia greca. Cefalu, Misuraca, 1978.

Pintacuda M. Interpretazioni musicali sul teatro di Aristofane. Palermo, Palumbo, 1982.

Putschen H. van (ed.) Grammaticae Latinae auctores antiqui. Hanoviae, Typis Wechelianis, 1605.

Rossbach A. Griechische Rhythmik. (Vol. 1 of: A. Rossbach; R. Westphal. Metrik der griechischen Dramatiker und Lyriker.) Leipzig, Teubner, 1854.

Rossi L.E. POxy 9 + POxy 2687: Trattato Ritmico-Metrico, in: A. Brancacci (ed.) Aristoxenica, Menandrea Fragmenta Philosophica. Studi e Testi per il Corpus dei Papiri Filosofici Greci e Latini. Firenze, Olschki, 1988, 11-30.

Salazar A. La musica en la cultura griega. Mexico, El colegio de México, 1954.

Schneidewin F. G. Delectus poetarum iambicorum et melicorum Graecorum. II. Gottingae, Vanderhoeck \& Ruprecht, 1839.

Sittl K. Geschichte der griechischen Literatur bis auf Alexander den Großen. 1. Teil. München, Ackermann, 1884.

Smyth H. W. Greek Melic Poets. London, Macmillan, 1904, repr. New York, Bibli \& Tannen, 1963.

Stahl W. H. Martianus Capella and the Seven Liberal Arts. Vol. I. The Quadrivium of Martianus Capella. Latin Tradition in the Mathematical Sciences. New York - London, Columbia University Press, 1971.

Studemund W. (ed.) Anecdota varia Graeca musica metrica grammatica. Berolini, Weidmann, 1886.

Van Groeningen B. A. A propos de Terpandre. Mnem. 1955, 8, 177-191.

Visconti A. Aristosseno di Taranto. Biografia e formazione spirituale. Naples, Centre Jean Bérard, 1999.

Volkmann R. (ed.) Plutarchi De musica. Leipzig, Teubner, 1856.

Weil H. Über Zahl und Anordnung der Arsen und Thesen in den verschidenen Rhythmengeschlectern der antiken Musik, Neue Jahrbücher für Philologie und Pädagogik 1855, 71, 396-402.

Weil H.; Reinach Th. (eds.) Plutarque. De la Musique. Édition critique et explicative. Paris, Leroux, 1900.

Wendel C. Philoxenos 27, RE 1941, 20, 194-200.

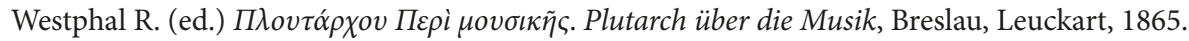

Westphal R. Griechische Rhythmik und Harmonik nebst der Geschichte der drei musischen Disciplinen. (Vol. I of: Rossbach, A; Westphal, R.Metrik der Griechen im Vereine mit den übrigen musischen Künsten.) Leipzig, Teubner, ${ }^{2} 1867$. 